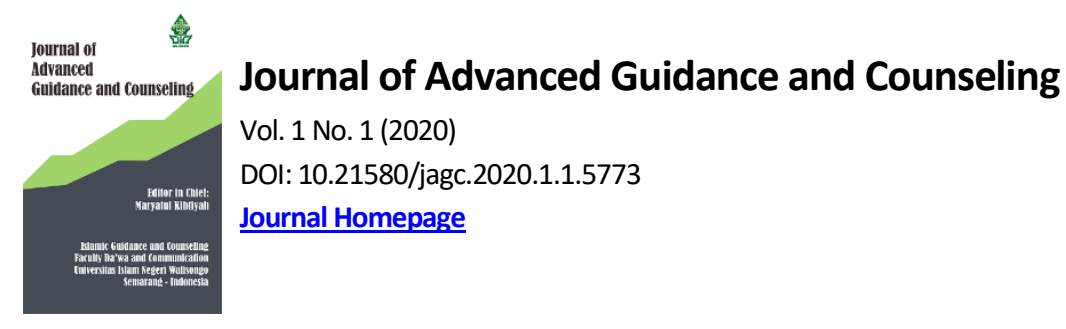

JAGC $\mid 58$

\title{
Dzikir as a therapy in sufistic counseling
}

\author{
Ade Sucipto \\ Universitas Negeri Semarang \\ email: adesucipto222@gmail.com
}

\begin{abstract}
This paper was aimed to provide knowledge that Dzikir can be used as an alternative therapy in sufistic counseling. Sufis have the view that all the problems faced by all individuals come from an uneasy heart or mind, so the first process of giving assistance to be done is to organize the heart or mind. Dzikir as a therapy in sufistic counseling is interesting to be studied further by using a grounded theory in qualitative research method. The results show that dhikr therapy is one of the sufistic counseling techniques that can be used to heal an uneasy heart or mind. Dzikir will make the counselee closer to the creator, namely Allah. In addition, dhikr makes the counselee aware of the essence of himself as a creature of God so that the powers of the soul emerge that will help the counselee overcome problems at hand.
\end{abstract}

Keywords: dzikir; therapy; sufistic counseling

\begin{abstract}
Abstrak
Tulisan ini bertujuan untuk memberikan pengetahuan bahwa berdzikir dapat dijadikan salah satu alternatif terapi dalam konseling sufistik. Para sufi mempunyai pandangan bahwa semua masalah yang dihadapi oleh semua individu berasal dari hati atau batin yang tidak tenang, sehingga proses pemberian bantuan yang pertama harus dilakukan adalah menata hati atau batin. Dzikir sebagai terapi dalam konseling sufistik menarik untuk dikaji lebih lanjut dengan menggunakan metode penelitian kualitatif jenis grounded theory. Hasilnya menunjukkan bahwa terapi dzikir merupakan salah satu teknik konseling sufistik yang dapat digunakan untuk menyembuhkan hati atau batin yang tidak tenang. Berdzikir akan menjadikan konseli lebih dekat dengan sang pencipta yaitu Allah. Selain itu berdzikir menjadikan konseli dapat menyadari esensi diri sebagai mahluk Allah, sehingga muncul kekuatan-kekuatan dari jiwa yang akan membantu konseli mengatasi maslaah masalah yang sedang dihadapi.
\end{abstract}

Kata kunci: dzikir; terapi; konseling sufistik 


\section{Introduction}

The industrial revolution which is increasingly developing makes technological developments more advanced. The era of the industrial revolution 4.0 is a new era in today's world. One of the characteristics is the interconnection to communicate via the internet of things or the internet of people. Technology in the 4.0 era certainly has a tremendous impact on human life biologically, socially and psychologically (Adiansah, et al: 2019). This is like two sides of a coin; it has positive impacts, and it also has negative ones.

Era 4.0 comes with positive and negative impacts on human life. In terms of development, era 4.0 provides many benefits in the form of convenience and makes it easier for individuals to do activities. However, other than the benefits, it also has various negative sides, such as de-humanization of modern society, disharmony in social ties, and erosion of spiritual values. Diseases felt by individuals are also various, such as physical illnesses and diseases of psychological origin. Efforts to treat diseases caused by physical conditions can use medical treatment. But if the disease is a sort of psychological origin, mental (psychic) medication must be used. Thus, many feel that the disruption era 4.0 has significant problems and effects felt by individuals in the economic, social, cultural, and spiritual fields (Khasali, 2018).

The problems felt by individuals will be accompanied by stress and depression or other mental disorders when the individuals do not have great and strong mental and spiritual strength to face the disruption era 4.0. Faith that is not strong enough is very vulnerable and prone to depression and stress. It is the strength of faith that will produce great and strong mental endurance. Such conditions allow individuals to have considerable inner contradictions. Conflicts arise as a result of an imbalance between the science and technology abilities possessed and spiritual abilities. The restlessness of mind will also spread to this human being. This has also led to the emergence of predictions known as futurologists in the era of globalization which will affect human psyche (Jalaludin, 2000). In such conditions, people will flock to look for inner comfort and enlightenment, including religion. 
Ade Sucipto

The phenomenon above explains that not all diseases experienced by individuals can be treated or cured with the sophistication of medical devices (medical drugs) (Solihin, 2004). The sophistication of medical devices in this era of JAGC | 60 disruption is accompanied by the development of alternative medicines existing everywhere. The presence of alternative medicine must be recognized for its benefits in contributing to the health of the community. When physical ailments can be cured, physical health will appear. However, when a mental illness is cured, healthy mental behaviors will appear. Diseases that occur in individuals cannot always be cured through medical treatment (Jalaludin, 2000). In such conditions, Sufism provides the answer to find the integrity of spiritual body in individuals. Sufism can be used as awareness for individuals to see the problems that occur in this era of disruption such as a humanitarian crisis that cannot be solved by intellectual reason but must balance with spiritual efforts. Spiritual religion makes the simplest form of various other religious and spiritual internalization actions (Thohir, 2013).

In general, Sufis or people who take up tasawuf view that the spiritual world can have implications for the material world. With that they introduced sufistic treatment or often referred to as sufistic psychotherapy. Sufistic therapy is a treatment with Islamic nuances with the aim of creating a human with a healthy spirit. The approach can be done through counseling, repentance approaches, dzikir approach, and so on (Solihin, 2004). Fazlurahman (1998) in his book, Health and Medicine in the Islamic Tradition Change and Identity, explains that treatment with Islamic nuances (spiritual) is important in today's disruption. One of the alternative treatments that use spiritual aspects is Sufistic therapy (Saifullah, 2018).

Some of the causes of problems that occur in individuals that can be quickly resolved when using the spiritual dimension method are awakening the potential for faith in God and then moving it towards inner enlightenment or spiritual enlightenment which essentially raises the confidence that God Almighty is the only power Healing illnesses suffered by (Abdurrahman, 2010). Thus, Sufistic therapy can be used as an alternative treatment for individuals who are in trouble and live far from the spiritual dimension. Sufistic therapy can be said to be the 
process of providing assistance through several therapies, such as prayer, mind healing therapy, Sufistic counseling or healing using Sufistic principles.

Sufistic counseling is one of the therapies in Sufistics that can be used as a method to optimize the potential of problematic individuals. Sufistic counseling as a form of effort to help individuals develop the "potential" that Allah SWT has and JAGC | 61 has given him. Sufistic counseling is an effort to solve problems experienced based on Islamic teachings by imitating the lives of Sufis in their relationship with Allah so that they can grow and develop optimally and in the end can live a peaceful and happy life in the world and the hereafter (Sutoyo, 2017).

\section{Research Method}

Based on the explanation above, it is necessary to conduct observations and research. This research type used was a qualitative research of grounded theory. The research design of Grounded theory is a procedure used to compile a theory or conceptual explanation of something conceptually (Egan, 2002). The research of Grounded theory is suitable to be used to explain a phenomenon, process or to formulate a conceptual on a particular phenomenon (Goddard, 2004). Departing from this understanding, this study was intended to study the theories of dzikr, counseling, and sufistics, which are expected to be able to find a more established theory formulation of dzikir as therapy in sufistic counseling.

\section{Results and Discussion}

\section{Dzikir}

Dzikir according to language can be interpreted as remembering, while according to the term it is to familiarize the tongue with utterances in the form of praise to Allah SWT (Nawawi, 2008). Dzikir is a type of worship that unites speech, heart, and no time limit. Thinking is not worship which is done by word of mouth, but it is carried out by heart (the most important dhikr). However, if it cannot be done with both, then it is best to dzikir with the heart. Even so, the heart doing dzikir and trying to present the meaning of dzikir in the heart, knowing the meaning of what is being said is something that must be pursued in dzikir (Nawawi, 2008). 
Ade Sucipto

According to Al-Ashfahani, dzikir is an effort to present something that is both in the form of feelings (hearts) and actions (Abdurrahman. 2010)

\section{Sufistic counseling}

JAGC | 62 Lubis (2007) formulates Islamic counseling as a service to help clients to a). recognize, know, and understand the situation according to its nature (fitrah); b). accept his condition as there are good and bad aspects, strengths and weaknesses as something that Allah SWT has established and then awakens people to make efforts and put their trust in solving all their problems; and c) understand the circumstances (situations and conditions) it faces. In this case, it helps to formulate problems, diagnose, and find alternatives to the problems it faces. Islamic counseling can be interpreted as a motivational process for individuals (humans) to have an awareness of "come back to religion" because religion will provide enlightenment on patterns of attitudes, thoughts, and behavior towards a sakinah, mawaddah, rahmah and ukhfuwwah personal and social life so that humans will avoid mental unhealthyness or individualistic traits, exploitative passions that create havoc on earth (Yusuf and Nurihsan, 2008).

Understanding the definition of Islamic counseling above, it can be understood that in fact Sufistic counseling is part of Islamic counseling which specifically applies Sufistic teachings in the process of counseling services carried out to clients (Hidayanti and Syukur, 2018). Sufistic counseling is an effort to help individuals to develop the "potential" that Allah SWT has and is bestowed upon him. Sufistic counseling is an alternative method to solve the problem at hand and the process of which always pays attention to Islamic teachings by always imitating the Sufi life in dealing with Allah. This is an effort so that individuals can grow and develop optimally and become pious individuals who are expected to be happy in the world and the hereafter (Sutoyo, 2017).

\section{Dzikir as a therapy in sufistic counseling}

The important essence of Sufi counseling is to imitate the morals of the Sufis which have been proven to be able to provide positive values for the practitioners. One of the benefits is to provide health effects both physically and spiritually 
(Hidayanti and Syukur, 2018). As Syukur said, Sufism as part of Islamic teachings demands how to restore health; free from disease not only physically but also psychologically (Gratitude, 2012).

One of the treatments listed in the Qur'an is physical and psychological practice. However, at the curative stage, the main thing is psychological treatment JAGC | 63 in the individual psyche. When the psyche in an individual is not healthy, it will be the cause of spiritual illness and will have an impact on physical illness. The soul is a very important part of human beings because it can affect the spiritual level. When the soul in the individual is clean, he will be closer to Allah. Meanwhile, when the soul is disturbed, the individual must try to purify the soul using a method that has been exemplified in Sufism (Mubasyaroh. 2017).

Thus, the meaning of Sufi counseling is the implementation of Sufistic values in this framework which is understood to follow the understanding of neo-Sufism which emphasizes moral motives and the application of the dhikr and muqorobah method or spiritual concentration to get closer to God (Hidayanti, 2017). Sufistic counseling that adopts the teachings of Sufism in helping patients solve their problems can be practiced by applying serious practices (riyadhah and mujahada) to clean, enhance and deepen spiritual values in order to get closer (taqarrub) to Allah, so, in that way, all one's concentration is only focused on God (Gratitude, 1999).

Sufistic counseling is full of healing therapies for physical, psychological, psychological or psychiatric, and spiritual diseases based on sufistic life (Abdurrahman, 2010). Sufis have developed procedures for providing mental therapy for individuals who need help by explaining and interviewing the counselee to walk towards spiritual perfection by optimizing faith in the heart who is facing problems. It invites the counselee to purify his heart or purify intentions, strengthen desires, and put trust in Allah SWT. Besides, he always be honest, sincere, and doing something lawful. Furthermore, it invites the counselee to heal a restless soul with dhikr to Allah, which can make the individual calm (An-najar, 2004). 
Ade Sucipto

Peace of mind is one of the conditions expected by every individual who is having problems (mental disorders). The way to restore peace of mind is to invite the individual back to the Creator or to return to the teachings of Islam. This can be JAGC | 64 done because dzikir can be an individual incentive to remember, mention , and can reduce back something that is hidden by his heart. Dzikr will also make individuals aware that it is Allah AWT who can make them healthy and avoid the problems they are facing. Dzikir is a form of worship that is exemplified by the Prophet Muhammad that can bring goodness and reward to individuals who do it, so that they will be protected from various diseases, both physical, mental and psychological diseases such as anxiety, stress, depression and so on. Allah "or" Asma Allah "repeatedly and continuously is one of the efforts that must be done to bring positive energy to individuals and stem the negative energy that will enter into the individuals.

This is the importance of the individual for dzikr in an effort to treat the problems at hand and shape the individual's personality. Individuals who always perform dzikr to Allah SWT will have their hearts melt and will always receive nourishment. Therefore, it will make the individual's heart a controlling center for the behavior to be carried out by the individuals. Dzikir will make individual's soul at ease so that he also acts in his daily life peacefully. Individuals who are diligent in practicing dzikr will be able to accept what happens to him and remembering that everything that happens to him is the will of Allah SWT. Allah SWT said (in Surah AlBaqarah / 2: 152.) "Therefore, remember you to me, I will certainly remember (also) you, and be thankful to me, and do not deny (Favors) me".

Sufistic counseling approach with dzikr therapy can improve the foundation of an individual and can realize his essence as a living being. Gradually, the technique will teach individuals to take lessons from the problems at hand, be patient, be grateful, and optimize their existing abilities to meet the needs of life without having to fall short of the rules of Islamic law or violate the rights of others. In addition, individuals will be more sensitive to heart impulses, have good feelings, can have optimal responsibility, accept any consequences of the choices they have chosen and will realize that everything present in their life is the permission of Allah 
SWT so that in their life they will always close to Allah and always hopes for His blessing (Rahman, 2017)

The reforts to achieve the pleasure of Allah SWT, in Sufistic counseling, apply several stages, such as the stages of al-Bidayah, takhalli, tahalli , tajalli, mujahadah, and riyadhah. The stage al-Bidayah (beginning) is that the individual begins to enter into the philosophical stages of takhalli (emptying the soul from everything that is noble), tahalli (filling the soul with obedience), and tajalli (finding what is looking for and applying it in everyday life). Then, it is continued with mujahadah and riyadhah, through maqamat and ahwal. Finally, it comes to the nihayah (end of the search). Sufis use the word nihayah as the last state or level, i.e.: wushul (attainment), ihsan (good deeds), or fana'(impermanence). Individuals who reach this level of manzilah are called ahl-irfani. However, for ordinary individuals (not knowing), there are many ways that can be done to carry out sufistic therapy. These paths are the same as what Sufis do by means of dzikr (Syukur. 2012).

Thus, it strengthens that dzikir can be used as a therapy in sufistic counseling. Dzikr is able to be a bridge for clients to increase awareness of Allah as the Creator. This initial awareness was built in the Sufi tradition with the hope of being able to bring out better behavior so that one can achieve inner calm in facing various life problems. This inner calm and clarity of heart are the keys for clients to maximize their potential in order to solve all the problems faced.

\section{Conclusion}

Sufistic counseling in the process of providing assistance focuses more on the emergence of energy within an individual. Sufistic counseling prioritizes inner healing in counselees; they think that people who have problems because their hearts are not calm. An uneasy heart will cause the counselee to lose control of his behavior causing the counselee to have problems. Conversely, when the counselee has peace of mind, he will have good mental and psychological health. Sufists believe that the root of all problems is the heart. Dzikir can be used as a therapy in sufistic counseling because it can be a medium for counselees to find peace of mind so that they have the power to solve the problems at hand. 
Ade Sucipto

\section{References}

Abdurrahman, Gusti. (2010). Terapi Sufistik untuk Penyembuhan Gangguan Kejiwaan. Yogyakarta: AswajaPressindo.

Adiansah, Wandi dkk. (2019). Person in Environment Remaja Pada Era Revolusi Industri 4.0. Jurnal Pekerja Sosial. Vol. 2 No 1. DOI : https://doi.org/10.24198/focus.v2i1.23118.

An-Najar, Amir. (2004). Psikoterapi Sufistik dalam Kehidupan Modern. ter. lja Suntana. Jakarta: MizanPublika

Egan, T, Marshall. (2002). Grounded Theory Research And Theory Building. Advences is Developing Human Resources, Vol.4, no.3. DOI: https://doi.org/10.1177/1523422302043004.

Goddard, A. (2004). Budgetary Practices Andaccountability Habitus: A Grounded Theory, Acountng. Auditing, \& Accountability Journal. Vol 17(4) . DOI: https://doi.org/10.1108/09513570410554551.

Hidayanti, Ema dan Amin, Syukur. (2018). Religious Coping Strategies Of HIV / AIDS Women And Its Relevance With The Implementation Of Sufistic Counseling In Health Services. Konseling Religi, Jurnal Bimbingan Dan Konseling Islam, Vol. 9 No. 2. DOI: $10.21043 / \mathrm{kr} . v 9 \mathrm{i} 2.4634$.

Hidayanti, Ema. (2017). Nilai-nilai Sufistik dalam Pelayanan Kesehatan : Studi terhadap Husnul Khatimah Care (Hu Care) di Rumah Sakit Nur Hidayah Bantul Yogyakarta. Konseling Religi Jurnal Bimbingan dan Konseling Islam, Vol. 8, No.1, Juni. DOI: 10.21043/kr.v8i1.2256.

Khasali, R. (2018). Strawberry Generation. Jakarta: Mizan

Lubis, Syaiful Akhyar Lubis. (2007). Konseling Islam Kyai Dan Pesantren. Yogyakarta : elSAQ Press.

Solihin, M. (2004). Penyembuhan Penyakit kejiwaan Perspektif Tasawuf. Bandung. Pustaka Setia.

Mubasyaroh. (2017). Pendekatan Psikoterapi islam dan konseling sufistik dalam menangani masalah kejiwaan. Konseling Religi: Jurnal Bimbingan Konseling Islam. Vol. 8, No. 1.

Nawawi, Ismail. (2008). Risalah Pembersih Jiwa: Terapi Prilaku Lahir \& Batin Dalam Perspektif Tasawuf. Surabaya: Karya Agung Surabaya 
Rahman, Dimas Kania Rahman. (2017). Gestalt Profetik (G-Pro) Best Practice Pendekatan Bimbingan Dan Konseling Sufistik. Konseling Religi: Jurnal Bimbingan Konseling Islam. Vol. 8, No. 1. DOl: 10.21043/kr.v8i1.2216.

Saifullah, S., Hasbullah, H., \& Hasbi, M. R. (2018). Terapi Sufistik dalam Pengobatan di Pekanbaru Riau. Al-Ulum, 18(2), 341-364. DOI: https://doi.org/10.30603/au.v18i2.496.

Syukur. M. Amin. (2012). Sufi Healing; Terapi dengan Metode Tasawuf . Jakarta: Erlangga.

Thohir, U. F. (2017). Tasawuf Sebagai Solusi bagi Problematika Kemodernan: Studi Pemikiran Tasawuf M. Amin Syukur. Asy-Syari'ah: Jurnal Hukum Islam, 3(2), 176-202. Retrieved from: https://www.ejournal.inzah.ac.id/index.php/assyariah/article/view/260.

Yusuf and Nurihsan. (2008). Landasan Bimbingan Dan Konseling. Bandung : Remaja Rosdakarya. 